\title{
Socioeconomic status and age at menarche in indigenous and non-indigenous Chilean adolescents
}

\author{
Nivel socioeconómico y edad de la menarquia en \\ adolescentes chilenas indígenas y no indígenas
}

${ }^{1}$ Faculdad de Medicina, Universidad de Chile,

Santiago, Chile.

Correspondence H. Amigo

Departamento de Nutrición, Faculdad de Medicina, Universidad de Chile. Independencia 1027,

Santiago, Región Metropolitana, 8389100, Chile.

hamigo@med.uchile.cl

\section{Abstract}

The objective was to analyze the relationship between socioeconomic status and age at menarche among indigenous and non-indigenous girls in the Araucanía Region of Chile, controlling for nutritional status and mother's age at menarche. A total of 8,624 randomly selected girls from 168 schools were screened, resulting in the selection of 207 indigenous and 200 non-indigenous girls who had recently experienced menarche. Age at

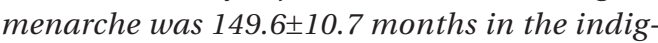
enous group and 146.6 \pm 10.8 months in the nonindigenous group. Among the non-indigenous, the analysis showed no significant association between age at menarche and socioeconomic status. In the indigenous group, age at menarche among girls with low socioeconomic status was 5.4 months later than among those with higher socioeconomic status. There were no differences in nutritional status according to socioeconomic level. Obesity was associated with earlier menarche. Menarche occurred earlier than in previous generations. An inverse relationship between socioeconomic status and age at menarche was seen in the indigenous group only; low socioeconomic status was associated with delayed menarche, regardless of nutritional status or mother's age at menarche.

Menarche; Social Class; South American Indians; Adolescent
Hugo Amigo 1

Sofía Vásquez ${ }^{1}$

Patricia Bustos 1

Guillermo Ortiz 1

Macarena Lara 1

\section{Introduction}

Menarche is a woman's first menstruation, an event that indicates sexual maturation and the beginning of reproductive life. Age at menarche is determined by multiple factors such as nutritional status, ethnic or racial background, birth weight, and mother's age at menarche, among others $1,2,3,4$.

Socioeconomic status has also been postulated as a determinant of age at menarche. According to previous studies, among girls from lower socioeconomic strata, menarche is delayed by exposure to adverse environmental and nutritional factors during early childhood or even deficient nutrition during adolescence 5,6,7,8,9. However, other studies indicate that among lower socioeconomic strata, menarche may occur earlier because rates of obesity and overweight are higher in such groups 10,11. Available information on the relationship between socioeconomic context and age at menarche is therefore contradictory, and further research is thus needed on this topic. To study this relationship, the target population's socioeconomic characteristics must be considered.

The current study was conducted in the Araucanía Region, the second poorest region in Chile. Twenty percent of the inhabitants live in poverty, and 30 percent in rural areas. Importantly, the region also has the largest proportion of indigenous 
inhabitants in Chile; this population is generally more socioeconomically disadvantaged 12 .

Studies have shown that the relationship between socioeconomic status and age at menarche is based on nutritional factors 9,10,11. Lifestyle changes in recent decades have led to an obesogenic environment which could result in earlier pubertal development and younger age at menarche 13 . In Chile, higher obesity prevalence has been reported among Mapuche (indigenous) as compared to non-Mapuche girls, and this trend is increasing 14,15. Meanwhile, menarche reportedly occurs later in Mapuche girls 16. One of the factors for this delay is believed to be the socioeconomic conditions in which Mapuche girls grow and develop.

The current study aimed to analyze the relationship between socioeconomic status and age at menarche among adolescents in the Araucanía Region in Chile, controlling for ethnicity (Mapuche versus non-Mapuche) and other possible confounding and interactive factors.

\section{Material and methods}

This cross-sectional study was carried out in the Araucanía Region of Chile from 2007 to 2010. For the study, 168 public schools located in 26 counties (of a total of 32; six were excluded because they lack an indigenous population) were randomly selected. These establishments constitute $80 \%$ of the schools with the highest concentration of indigenous students. In each school, all girls 8 to 16 years of age who participated voluntarily were interviewed. This group consisted of 8,624 adolescents, or $98 \%$ of all the female students.

Screening used an interview that included questions on date of menarche and parents' last names. Girls who had experienced menarche in the three months prior to the interview were selected (207 indigenous and 200 non-indigenous adolescents). Last names were used to identify ethnicity. A recent study had identified and validated more than 7,000 Mapuche surnames, which were used as the reference 17 . Girls with three or four Mapuche surnames were defined as Mapuche, while those whose mother and father had Spanish surnames were defined as nonindigenous. Adolescents with non-Spanish surnames or for whom one parent's surname was not known were excluded from the study.

A home interview was also conducted to determine the socioeconomic characteristics of each subject's family. Socioeconomic status was defined with a matrix that included the head of household's educational level (no schooling, incomplete primary school, complete primary, incomplete secondary, complete secondary, incomplete vocational, and university) and household assets (shower, color TV, refrigerator, washing machine, water heater, microwave oven, car, cable or satellite TV, computer, Internet access), according to a socioeconomic classification that has been widely used and validated in Chile 18 . Factors included in this classification are relate to family income, cultural level, and accumulated wealth. The matrix divides the population into five socioeconomic strata $(\mathrm{ABC} 1, \mathrm{C} 2, \mathrm{C} 3, \mathrm{D}$, and E). Due to study sample's characteristics, strata $\mathrm{ABC} 1, \mathrm{C} 2$, and $\mathrm{C} 3$ were grouped into the middle socioeconomic status (importantly, there was only one subject from stratum $\mathrm{ABC}$ ), stratum $\mathrm{D}$ was classified as lower middle, and stratum E as lower socioeconomic status.

The students' height and weight were measured. Height was measured with an anthropometer, accurate to $1 \mathrm{~mm}$, and weight was measured with a digital scale (Seca, Hamburg, Germany), accurate to $100 \mathrm{~g}$. Subjects wore light clothing and no shoes while measurements were taken. The instruments were calibrated regularly. The procedures were performed by trained nursemidwives with ongoing quality control of data in accordance with internationally recommended standardization techniques for anthropometric measurements ${ }^{19}$. Body mass index (BMI) at menarche was estimated using data collected in the anthropometric evaluation. The National Center for Health Statistics/Centers for Disease Control and Prevention (NCHS/CDC) references 20 were used to classify the adolescents as normal weight with BMI from the $10^{\text {th }}$ to the $84^{\text {th }}$ percentiles, overweight with BMI from the $85^{\text {th }}$ to the $94^{\text {th }}$ percentiles, and obese with BMI was equal to or greater than the $95^{\text {th }}$ percentile. The NCHS/CDC tables were used because the Chilean Ministry of Health recommends this reference for evaluating the nutritional status of children 6 to 18 years of age and because other updated tables such as that of the World Health Organization (WHO), proposed in 2007 21, have not been widely used or validated in Chile.

The study used double data entry with Epidata (Epidata Association, Odense, Denmark), while data processing used SPSS 18.0 (SPSS Corp., Chicago, USA). Univariate and multivariate models were used for the analysis.

Initially, the means were compared using ANOVA to verify statistical differences, and univariate associations were analyzed between the different independent variables (socioeconomic status, ethnicity, BMI, and nutritional status at menarche and mother's age at menarche) and girl's age at menarche as the dependent variable. In the multivariate analysis, the relation- 
ship between socioeconomic status and age at menarche was verified, controlling for ethnicity, overweight and obesity (both in the same variable) at menarche and mother's age at menarche, through linear regression with prior confirmation of the normal distribution of residuals using the Shapiro-Wilk test.

The study was approved by the Research Ethics Committee of the School of Medicine at the Universidad de Chile. Prior to participating in the study, the girls and their mothers signed informed consent forms.

\section{Results}

A total of 407 cases were analyzed, of whom $51 \%$ were indigenous girls. The indigenous group consisted predominantly of adolescents from the lower socioeconomic stratum (slightly more than half), followed by the lower-middle stratum (38\%). In the non-Mapuche group, $46 \%$ belonged to the middle stratum and $43 \%$ to the lower-middle stratum. Thus, the lowest stratum consisted mostly of Mapuche girls, while the middle stratum included mainly non-Mapuche girls (Table 1).

Menarche occurred three months later in the Mapuche as compared to non-Mapuche girls $(p=0.006)$. The indigenous group showed a gradient for age at menarche that was dependent on socioeconomic status; menarche occurred six months later in the lower as compared to middle socioeconomic stratum $(\mathrm{p}$ trend $=0.012$ ). The
non-Mapuche group also showed a gradient, but statistically insignificant $(\mathrm{p}$ trend $=0.165$ ). Mean maternal age at menarche was six months greater than for the daughters, with a significant difference in both ethnicities ( $p<0.001)$. No relationship was detected between maternal age at menarche and socioeconomic status, nor were there any differences according to ethnicity $(\mathrm{p}=0.12)$. $\mathrm{BMI}$ at menarche was 1 point higher in Mapuche girls $(p=0.002)$ than in their non-Mapuche peers, while neither ethnic group showed differences in BMI according to socioeconomic status (Table 1). Concerning nutritional status, $34.3 \%$ and $9.7 \%$ of Mapuche girls presented overweight and obesity, respectively, as compared to $18 \%$ and $10 \%$, respectively, in the non-Mapuche group. Neither group showed an association between socioeconomic level and nutritional status.

The study showed significant interaction between socioeconomic status and ethnicity, so the linear regression was performed separately for each ethnic group. Among non-Mapuche girls, neither the adjusted or unadjusted model showed a significant association between age at menarche and socioeconomic status. In the Mapuche group, age at menarche in the lowest socioeconomic stratum was nearly six months higher than in the highest socioeconomic stratum in the unadjusted model and 5.4 months higher in the adjusted model $(\mathrm{p}<0.05)$. Menarche also occurred later in the lower-middle as compared to middle stratum in both ethnic groups, but without statistical significance (Tables 2 and 3).

Table 1

Characteristics of the study population according to ethnicity and socioeconomic status. Araucanía Region, Chile, $2007-2010$.

\begin{tabular}{|c|c|c|c|c|c|c|c|c|c|c|}
\hline \multirow[t]{2}{*}{ Factors } & \multicolumn{5}{|c|}{$\begin{array}{l}\text { Mapuche }(n=207) \\
\text { Socioeconomic status }\end{array}$} & \multicolumn{5}{|c|}{$\begin{array}{c}\text { Non-Mapuche }(n=200) \\
\text { Socioeconomic status }\end{array}$} \\
\hline & $\begin{array}{l}\text { Middle } \\
(n=21)\end{array}$ & $\begin{array}{l}\text { Lower middle } \\
\qquad(n=80)\end{array}$ & $\begin{array}{l}\text { Lower } \\
(n=106)\end{array}$ & p-value & $\begin{array}{c}\text { Total } \\
(\mathrm{n}=207)\end{array}$ & $\begin{array}{l}\text { Middle } \\
(\mathrm{n}=92)\end{array}$ & $\begin{array}{l}\text { Lower middle } \\
\qquad(n=86)\end{array}$ & $\begin{array}{l}\text { Lower } \\
(n=22)\end{array}$ & p-value & $\begin{array}{c}\text { Total } \\
(\mathrm{n}=200)\end{array}$ \\
\hline $\begin{array}{l}\text { Girl's age at } \\
\text { menarche } \\
\text { in months * }\end{array}$ & $145.3(12.17)$ & $148.6(10.89)$ & $151.2(10.08)$ & $\begin{array}{l}0.041^{\star \star} \\
0.012^{\star \star \star}\end{array}$ & $149.6(10.73)$ & $145.4(11.00)$ & $147.6(11.41)$ & $148.0(7.06)$ & $\begin{array}{l}0.332 * \star \\
0.165^{\star \star \star}\end{array}$ & $146.6(10.83)$ \\
\hline $\begin{array}{l}\text { Mother's } \\
\text { age at } \\
\text { menarche } \\
\text { in months * }\end{array}$ & $152.9(16.68)$ & $157.8(17.35)$ & $154.4(16.81)$ & 0.363 & $155.8(16.16)$ & $152.9(16.68)$ & $153.6(17.35)$ & 154.4 (12.99) & 0.915 & $153.3(16.54)$ \\
\hline $\begin{array}{l}\text { Girl's BMI at } \\
\text { menarche * }\end{array}$ & $22.1(2.51)$ & $21.2(3.55)$ & $21.9(3.00)$ & 0.221 & 21.7 (3.19) & $20.6(3.63)$ & 20.7 (3.79) & $20.3(2.30)$ & 0.933 & $20.6(3.57)$ \\
\hline
\end{tabular}

* Mean \pm (standard deviation);

** $p$ of heterogeneity;

$\star \star \star p$ for trend. 
Age at menarche according to socioeconomic status in indigenous girls (adjusted and unadjusted models). Araucanía Region, Chile, 2007-2010.

\begin{tabular}{|c|c|c|c|c|c|c|}
\hline \multirow[t]{3}{*}{ Socioeconomic status } & \multicolumn{6}{|c|}{ Age at menarche (in months) } \\
\hline & \multicolumn{3}{|c|}{ Unadjusted } & \multicolumn{3}{|c|}{ Adjusted * } \\
\hline & B coefficient & $95 \% \mathrm{Cl}$ & $p$-value & B coefficient & $95 \% \mathrm{Cl}$ & $p$-value \\
\hline Lower middle & 3.31 & $-1.81 ; 8.44$ & 0.204 & 2.02 & $-3.02 ; 7.05$ & 0.427 \\
\hline Lower & 5.884 & $0.88 ; 10.88$ & 0.021 & 5.40 & $0.49 ; 10.27$ & 0.030 \\
\hline
\end{tabular}

Calculations were performed using the middle socioeconomic stratum as the reference.

* Adjusted for overweight and obesity (grouped) at menarche and mother's age at menarche.

\section{Table 3}

Age at menarche according to socioeconomic status in non-indigenous girls (adjusted and unadjusted models). Araucanía Region, Chile, 2007-2010.

\begin{tabular}{|c|c|c|c|c|c|c|}
\hline \multirow{3}{*}{$\begin{array}{l}\text { Socioeconomic } \\
\text { status }\end{array}$} & \multicolumn{6}{|c|}{ Age at menarche (in months) } \\
\hline & \multicolumn{3}{|c|}{ Unadjusted } & \multicolumn{3}{|c|}{ Adjusted * } \\
\hline & B coefficient & $95 \% \mathrm{Cl}$ & $p$-value & B coefficient & $95 \% \mathrm{Cl}$ & $p$-value \\
\hline Lower middle & 2.20 & $-1.00 ; 5.40$ & 0.177 & 2.15 & $-0.78 ; 5.13$ & 0.150 \\
\hline Lower & 2.57 & $-2.49 ; 7.64$ & 0.318 & 1.96 & $-2.69 ; 6.72$ & 0.406 \\
\hline
\end{tabular}

Calculations were performed using the middle socioeconomic stratum as the reference.

* Adjusted for overweight and obesity (grouped) at menarche and mother's age at menarche.

In the latter analysis, excess weight (overweight and obesity) was associated with four months' earlier age at menarche in Mapuche girls and eight months in non-Mapuche girls (p $<0.01$ ).

\section{Discussion}

This study showed an inverse relationship between socioeconomic status and age at menarche in the indigenous population only; in other words, lower socioeconomic status was associated with a delay in menarche in the Mapuche population, regardless of the girl's nutritional status or mother's age at menarche. Overweight and obesity were also determining factors in early menarche, and menarche occurred earlier than in the previous generation.

The association between age at menarche and socioeconomic status in this study was similar to that found by Roman et al. 9, who used a socioeconomic stratification system that also included schooling and household assets. In both stud- ies, menarche occurred significantly later among girls in the lower socioeconomic stratum. Importantly, other studies corroborate the current study's findings, despite differences in the socioeconomic classification systems 5,7,8,22. However, the current study's findings disagree with others from Chile three years ago and those of studies in other countries, possibly due to the use of different methodologies to define socioeconomic status, based on indirect and/or aggregate information, or because the study populations were more socially heterogeneous.

According to this study, menarche occurs earlier among contemporary Chilean girls as compared to their mothers. This trans-generational shift has already been documented in Chile and is known as the secular trend in age at menarche, a phenomenon also found in the United States, elsewhere in Latin America, and Europe 23,24,25. Studies in Germany and Turkey indicate that age at menarche has stabilized, which may be evidence that optimal conditions for pubertal development were reached several years ago 26,27 . This situation has still not been reached in countries 
undergoing a rapid epidemiological transition and/or in an intermediate development phase, such as Chile and Mexico 28,29. Brazilian studies indicate that the secular trend in age at menarche is more intense in lower as compared to higher socioeconomic strata (in the latter, the trend has also tended to stabilize) 22 . In the current study, all socioeconomic strata showed significant differences in the girls' age at menarche compared to that of their mothers, suggesting that stabilization is still a long way off, at least in the highest socioeconomic stratum.

No association was found between current socioeconomic status and mother's age at menarche, possibly because socioeconomic status was defined in the present as opposed to SES at the time of the mother's menarche. Current socioeconomic status does not represent the social conditions that prevailed decades earlier, when the mothers experienced menarche. This finding is interesting, possibly suggesting that socioeconomic differences between these groups were not so evident in the past. Chile has experienced a decrease in the number of people living in poverty in recent decades, but this trend has not been identical for all socioeconomic strata or ethnic groups. Socioeconomic development has not reached the same level among indigenous people as compared to the non-indigenous population 30 .

The study also corroborated that overweight and obesity contribute to earlier menarche. Interestingly, Mapuche adolescents experienced menarche three months later than their nonMapuche peers, and BMI at menarche was also significantly higher. According to multivariate analysis, ethnicity does not appear to be a significant determinant of age at menarche; rather, delayed menarche is primarily due to the Mapuche people's adverse socioeconomic conditions. Age at menarche may thus be considered a possible indicator of socioeconomic development, as suggested by other studies 5 .

Nutritional status has been postulated as a factor connecting socioeconomic status to age at menarche. Thus, according to studies in Brazil, children with high socioeconomic status showed higher overweight and obesity rates, coinciding with earlier pubertal development. The effect of excess weight has also been reported by studies in Chile, showing that girls with low socioeconomic status were more likely to have excess weight and earlier menarche 9,10 . The current study found no significant differences between socioeconomic levels and BMI or nutritional status, so there may be other factors connecting socioeconomic status and age at menarche. Studies in Africa have suggested that malnutrition in early childhood can delay pubertal development, menarche, and other growth processes ${ }^{31}$. It is unlikely that this would explain the findings among girls in the current study, since nutritional status during early childhood is adequate in Chile, and malnutrition is rare among children under six years of age 32 .

The study's limitations include the diverse social composition of the two ethnic groups, since indigenous socioeconomic conditions are quite different from those of the non-indigenous population. Indigenous Chileans belong primarily to the lower middle and lower socioeconomic strata, while non-indigenous belong mostly to the middle and lower-middle strata.

Another limitation was that the sample (regardless of ethnicity) was concentrated mainly in classes $\mathrm{C} 2, \mathrm{D}$, and $\mathrm{E}$, the three lowest socioeconomic categories. If the study population had been more representative of the middle and upper strata, differences in age at menarche between adolescents from the lowest and highest strata would probably have been more pronounced. However, the socioeconomic profile of the Araucanía Region does not allow for a more socially heterogeneous sample. Another weak point in the study was the retrospective collection of data on mother's age at menarche, an event that would have occurred about 20 years earlier. Recall bias by mothers is likely, thus influencing the results, with imprecise time of menarche (even though this would apply to both ethnic groups).

The study's strengths included directly obtaining the girls' precise age at menarche (exact date) and corroborating it with their mothers, so that the study only included girls who had experienced menarche in the three months prior to the interview. Another advantage was the collection of reliable information on household assets and parental schooling through the family survey and the use of a socioeconomic stratification system previously validated for the Chilean population. Finally, data were gathered by university graduates who had undergone previous training and were constantly supervised during the fieldwork.

Complementary research could examine the relationship between socioeconomic status and age at menarche in a more heterogeneous population in order to compare the results in different socioeconomic strata. Meanwhile, such studies could help elucidate the mechanisms by which socioeconomic conditions influence age at menarche. Thus far, the evidence supports the important role of nutritional factors both before and during puberty. 


\section{Resumen}

El objetivo fue analizar la relación entre nivel socioeconómico y edad de menarquia en adolescentes indígenas y no indígenas de la Región de la Araucanía, Chile, controlando el efecto del estado nutricional, y la edad de menarquia de las madres. Se estudiaron 8.624 niñas de 168 escuelas elegidas aleatoriamente, seleccionando 207 indígenas y 200 no indígenas que habían tenido recientemente la menarquia. La edad

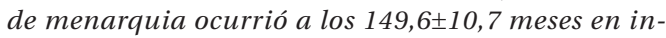
dígenas y a los 146,6 $\pm 10,8$ meses en no indígenas. En el grupo no indígena, hubo una relación significativa entre edad de menarquia y nivel socioeconómico. En el grupo indígena, edad de menarquia del nivel socioeconómico bajo fue de 5,4 meses más tarde que el nivel socioeconómico más alto. No se observaron diferencias de estado nutricional por nivel socioeconómico. La obesidad adelantó la menarquia y la edad de menarquia ocurrió antes que la de sus madres. Existe una relación inversa entre nivel socioeconómico y edad de menarquia sólo en el grupo indígena; en los niveles socioeconómicos más bajos la edad de menarquia se retrasa independiente del estado nutricional y de la edad de menarquia de la madre.

Menarquia; Clase Social; Indios Sudamericanos; Adolescente

\section{Contributors}

H. Amigo designed the study, conducted the data analysis, and participated in writing the article. S. Vásquez participated in the data processing and analysis and writing the manuscript. P. Bustos participated in planning the fieldwork and contributed to writing and revising the final version of the article. G. Ortiz participated in the data processing and analysis and revision of the manuscript. M. Lara participated in the data analysis and revision of the manuscript.

\section{Acknowledgments}

The authors wish to thank nurse-midwife Elba Contreras for data recovery and medical student Eloísa Pérez for development of the database. Acknowledgments are also due to Fondo Nacional para Ciencia y Tecnologia de Chile (Proyecto Fondecyt 1060884).

\section{References}

1. Rosenfield RL, Lipton RB, Drum ML. Thelarche, pubarche, and menarche attainment in children with normal and elevated body mass index. Pediatrics 2009; 123:84-8.

2. Salsberry PJ, Reagan PB, Pajer K. Growth differences by age of menarche in African American and White girls. Nurs Res 2009; 58:382-90.

3. Terry MB, Ferris JS, Tehranifar P, Wei Y, Flom JD. Birth weight, postnatal growth, and age at menarche. Am J Epidemiol 2009; 170:72-9.

4. Wronka I. Association between BMI and age at menarche in girls from different socio-economic groups. Anthropol Anz 2010; 68:43-52.
5. Chavarro J, Villamor E, Narvaez J, Hoyos A. Sociodemographic predictors of age at menarche in a group of Colombian university women. Ann Hum Biol 2004; 31:245-57.

6. Tavares CH, Haeffner LS, Barbieri MA, Bettiol H, Barbieri MR, Souza L. Idade da menarca em escolares de uma comunidade rural do Sudeste do Brasil. Cad Saúde Pública 2000; 16:709-15.

7. Orden AB, Vericat A, Apezteguia MC. Age at menarche in urban Argentinian girls: association with biological and socioeconomic factors. Anthropol Anz 2011; 68:309-22. 
8. Rebacz E. Age at menarche in schoolgirls from Tanzania in light of socioeconomic and sociodemographic conditioning. Coll Antropol 2009; 33:23-9.

9. Roman EP, Ribeiro RR, Guerra-Junior G, BarrosFilho AA. Anthropometry, sexual maturation and menarcheal age according to socioeconomic status of schoolgirls from Cascavel (PR). Rev Assoc Med Bras 2009; 55:317-21.

10. Hernandez MI, Unanue N, Gaete X, Cassorla F, Codner E. Age of menarche and its relationship with body mass index and socioeconomic status. Rev Med Chile 2007; 135:1429-36.

11. Kirchengast S, Bauer M. Menarcheal onset is associated with body composition parameters but not with socioeconomic status. Coll Antropol 2007; 31:419-25.

12. Ministerio de Desarrollo Social, Gobierno de Chile. Pueblos indígenas. Encuesta CASEN 2009. http://www.ministeriodesarrollosocial.gob.cl/cas en2009/indigenas.pdf (accessed on 14/Dec/2011).

13. Codner E, Unanue N, Gaete X, Barrera A, MookKanamori D, Bazaes R, et al. Age of pubertal events in Chilean school age girls and its relationship with socioeconomic status and body mass index. Rev Med Chile 2004; 132:801-8.

14. Amigo H, Bustos P, Erazo M, Radrigan ME. Nutritional status of school children from indigenous and non indigenous ancestry. Rev Med Chile 1999; 127:903-10.

15. Bustos P, Munoz S, Vargas C, Amigo H. Evolution of the nutritional situation of indigenous and nonindigenous Chilean schoolchildren. Ann Hum Biol 2009; 36:298-307.

16. Amigo H, Bustos P, Muzzo S, Alarcon AM, Munoz S. Age of menarche and nutritional status of indigenous and non-indigenous adolescents in the Araucania Region of Chile. Ann Hum Biol 2010; 37:554-61.

17. Amigo H, Bustos P. Apellidos mapuche. Historia y significados. Santiago: Impresos Maigret; 2008.

18. ADIMARK. El nivel socio económico Esomar. Manual de aplicación, 2000. http://www.microweb. $\mathrm{cl} /$ idm/documentos/ESOMAR.pdf (accessed on 20/Jan/2010).

19. de Onis M, Onyango AW, Van den Broeck J, Chumlea WC, Martorell R. Measurement and standardization protocols for anthropometry used in the construction of a new international growth reference. Food Nutr Bull 2004; 25(1 Suppl):S27-36.

20. National Center for Health Statistics/Centers for Disease Control and Prevention. Growth charts for the United States: methods and development, 2002. http://www.cdc.gov/growthcharts/data_ta bles.htm (accessed on 14/Dec/2011).
21. National Center for Health Statistics/Centers for Disease Control and Prevention. CDC growth charts: United States, 2007. http://www.cdc.gov/ nchs/about/major/nhanes/growthcharts/data files.htm (accessed on 09/Aug/2011).

22. Junqueira Do Lago M, Faerstein E, De Souza Lopes C, Werneck GL. Family socio-economic background modified secular trends in age at menarche: evidence from the Pro-Saude Study (Rio de Janeiro, Brazil). Ann Hum Biol 2003; 30:347-52.

23. Quevedo I, Flores M, Castillo M. Reproductive history of women consulting in emergency services in a southern region of Chile. Rev Med Chile 2005; 133:929-34.

24. Cabanes A, Ascunce N, Vidal E, Ederra M, Barcos A, Erdozain N, et al. Decline in age at menarche among Spanish women born from 1925 to 1962. BMC Public Health 2009; 9:449.

25. Kaplowitz P. Pubertal development in girls: secular trends. Curr Opin Obstet Gynecol 2006; 18:487-91.

26. Gohlke B, Woelfle J. Growth and puberty in German children: is there still a positive secular trend? Dtsch Arztebl Int 2009; 106:377-82.

27. Atay Z, Turan S, Guran T, Furman A, Bereket A. Puberty and influencing factors in schoolgirls living in Istanbul: end of the secular trend? Pediatrics 2011; 128:e40-5.

28. Ossa XM, Munoz S, Amigo H, Bangdiwala SI. Secular trend in age at menarche in indigenous and nonindigenous women in Chile. Am J Hum Biol 2010; 22:688-94.

29. Mendez Estrada RO, Valencia ME, Melendez Torres JM. The menarche age in teenagers of the Northwest of Mexico. Arch Latinoam Nutr 2006; 56:160-4.

30. Ministerio de Desarrollo Social, Gobierno de Chile. CASEN 2009, Encuesta de caracterización socioeconómica nacional. http://www.ministerio desarrollosocial.gob.cl/casen2009/RESULTADOS_ CASEN_2009.pdf (accessed on 14/Dec/2011).

31. Simondon KB, Simondon F, Simon I, Diallo A, Benefice E, Traissac P, et al. Preschool stunting, age at menarche and adolescent height: a longitudinal study in rural Senegal. Eur J Clin Nutr 1998; 52:412-8.

32. Ministerio de Salud, Gobierno de Chile. Diagnóstico nutricional integrado de la población menor de 6 años bajo control, según regiones, 2010. http://163. 247.51.54/EstadoNutricional/17052011/Nutri cion_Infantil2008.htm (accessed on 14/Dec/2011).

Submitted on $06 /$ Sep/2011

Final version resubmitted on 21/Dec/2011 Approved on 05/Jan/2012 